\title{
Calcium content, in vitro digestibility, and bioaccessibility in

\author{
leaves of spinach (Spinacia oleracea), sweet potato (Ipomea
}

\section{batatas), and drumstick tree (Moringa oleifera) [version 1; peer}

\section{review: 3 approved with reservations]}

\author{
Jonathan C. Allen'1, Joseph Y. Issa2', Weiting Cai \\ ${ }^{1}$ Department of Food, Bioprocessing and Nutrition Science, North Carolina State University, Raleigh, NC 27695-7624, USA \\ ${ }^{2}$ Malawi Industrial Research and Technology Development Centre, Blantyre, Malawi, Malawi \\ ${ }^{3}$ Purall (Shanghai) Import \& Export Co. Ltd, Shanghai Shi, Shanghai, China
}

V1 First published: 03 Mar 2014, 3:65

https://doi.org/10.12688/f1000research.3287.1

Latest published: 03 Mar 2014, 3:65

https://doi.org/10.12688/f1000research.3287.1

\section{Open Peer Review}

\begin{tabular}{cccc} 
Approval Status ? ? ? & \\
& 1 & 2 & 3 \\
\hdashline & $?$ & $?$ & $?$ \\
version 1 & $?$ & view & view \\
03 Mar 2014 & view &
\end{tabular}

1. Mark L Failla, Ohio State University, Columbus, OH, USA

2. Antonio Cilla, University of Valencia, Burjassot, Valencia, Spain

3. Linda Mårtensson, Swedish University of

Agricultural Science, Uppsala, Sweden

Any reports and responses or comments on the article can be found at the end of the article. 
that increased utilization of Ipomea batatas and Moringa oleifera leaves might increase calcium intake in people in tropical and warm temperate regions where these plants grow, or these plants might become a valuable export crop.

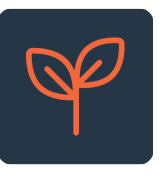

This article is included in the Agriculture, Food and Nutrition gateway.

Corresponding author: Jonathan C. Allen (Jon_allen@ncsu.edu)

Competing interests: The authors have no competing interests in the publication of this paper.

Grant information: This research was supported by grants from USAID - UILTCB-Malawi in a subcontract from Michigan Sate University, and by the North Carolina Sweet Potato Commission to author JCA.

The funders had no role in study design, data collection and analysis, decision to publish, or preparation of the manuscript.

Copyright: ( 2014 Allen JC et al. This is an open access article distributed under the terms of the Creative Commons Attribution License, which permits unrestricted use, distribution, and reproduction in any medium, provided the original work is properly cited. Data associated with the article are available under the terms of the Creative Commons Zero "No rights reserved" data waiver (CC0 1.0 Public domain dedication).

How to cite this article: Allen JC, Issa JY and Cai W. Calcium content, in vitro digestibility, and bioaccessibility in leaves of spinach ( Spinacia oleracea), sweet potato ( Ipomea batatas), and drumstick tree ( Moringa oleifera) [version 1; peer review: 3 approved with reservations] F1000Research 2014, 3:65 https://doi.org/10.12688/f1000research.3287.1

First published: 03 Mar 2014, 3:65 https://doi.org/10.12688/f1000research.3287.1 


\section{Introduction}

Calcium is an essential element responsible for bone strength and regulation of numerous functions in cells and tissues, such as muscle contraction and exocytosis. Approximately 1 to $2 \%$ of the human body is calcium. Perhaps $99 \%$ of that quantity is immobilized in bones and teeth. The remaining $1 \%$ is either ionized calcium or bound in soft tissues in a way that can more readily transfer among tissue compartments. Dietary calcium is absorbed by both active transport and passive diffusion across the intestinal mucosa. Active transport of calcium ions into enterocytes and out on the serosal side depends on the action of 1,25-dihydroxyvitamin D and its intestinal receptors. However, passive diffusion involves the movement of calcium between mucosal cells, is dependent on the luminal:serosal calcium concentration gradient, and may involve low-molecular weight calcium complexes in addition to calcium ions ${ }^{1}$.

Calcium deficiency diseases can result from low calcium intake (primary deficiency), poor calcium absorption (secondary deficiency), or excessive calcium losses. Calcium insufficiency in various life stages may be associated with osteoporosis, hypertension, colon cancer or other diseases. Individuals who do not have access, do not tolerate, or prefer not to consume milk and dairy products may prefer or require, plant sources of calcium. However, calcium bioavailability may be reduced in plant foods due to binding to oxalates or phytate, or to minerals competing for absorptive pathways. Benway and Weaver ${ }^{2}$ reported in vitro bioavailability for calcium of $0.3,26$ and $76 \%$ for spinach, wheat, and kale, respectively. Rapidly growing spinach forms high concentrations of insoluble calcium oxalate when the growth medium is high in available calcium ${ }^{3}$. High levels of oxalate were also observed in the leaves of sweet potato (Ipomea batatas) ${ }^{4}$. The formation of calcium oxalate crystals in numerous plant species may be beneficial to the plant but may be deleterious to human and animal consumers of plant tissues ${ }^{5}$. The leaves of the sweet potato are rarely consumed in Western countries but are a staple food or a delicacy in many African countries, including Zimbabwe, Zambia and Nigeria where the fresh leaves are cooked ${ }^{6}$. Different varieties are sometimes selected for leaf and root consumption. Purple and green sweet potato leaves in Tanzania were shown to contain significant quantities of nutritional and antinutritional compounds ${ }^{7}$. Purple sweet potato leaves that are commonly consumed in Asian countries have been investigated for the bioactivity of their polyphenol content ${ }^{8}$.

Moringa oleifera (drumstick tree) grows in tropical and sub-tropical climates. In the tropical regions of Asia, Africa and South America, leaves from both naturally occurring and cultivated Moringa are eaten fresh. The fruits, the flowers and the immature pods of this tree are also edible and they are used to varying extents in traditional diets in many tropical and sub-tropical regions ${ }^{9}$. In addition, M. oleifera is used as a medicinal plant ${ }^{10}$. In traditional herbal medicine different ethnic groups use parts of the Moringa tree differently ${ }^{11}$. As a traditional food plant in Africa, M. oleifera has the potential to improve nutrition, boost food security, foster rural development, and support sustainable land care. In some parts of the world such as Senegal and Haiti, health workers have been treating malnutrition in small children, pregnant and nursing women with Moringa leaf powder ${ }^{12}$. The leaves of M. oleifera are a good source of protein, vitamin A, B and C and minerals such as calcium and iron ${ }^{13}$.
Oduro et al. ${ }^{14}$ found the calcium content in $M$. oleifera to average $2009 \mathrm{mg}$ per $100 \mathrm{~g}$ sample. According to Price ${ }^{12}$, M. oleifera fresh pods and leaves and dried leaf powder had $30 \mathrm{mg}, 440 \mathrm{mg}$ and $2003 \mathrm{mg}$ per $100 \mathrm{~g}$ of edible portion, respectively. A study on the nutritional and functional properties of $M$. oleifera leaves found that fresh mature leaves and fresh young shoots had $454 \pm 63 \mathrm{mg}$ and $82 \pm 31 \mathrm{mg}$ of calcium per $100 \mathrm{~g}$ of sample, respectively ${ }^{15}$. A previous study on in vitro iron bioavailability found that boiling the fresh leaves and dried powder of $M$. oleifera enhanced the in vitro iron bioavailability by 3.5 and 3 times, respectively ${ }^{16}$. The USDA Nutrient Database lists $152 \mathrm{mg}$ of calcium per $100 \mathrm{~g}$ of boiled drumstick leaves, $136 \mathrm{mg}$ of calcium per $100 \mathrm{~g}$ of boiled spinach, and $33 \mathrm{mg}$ of calcium per $100 \mathrm{~g}$ of boiled sweet potato leaves (http://ndb.nal.usda.gov/ndb/ search/list). Although the literature shows high calcium content in these plant materials, there are fewer data on the calcium bioavailability. The study reported here was therefore designed to investigate the potential calcium bioavailability in spinach (Spinacia oleracea), sweet potato (Ipomea batatas), and drumstick tree (Moringa oleifera) leaves by measuring bioaccessibility using an in vitro simulated digestive system. True bioavailability cannot be determined from an in vitro system because it does not distinguish between forms of calcium that can be absorbed by regulated active transport processes and passive absorption, nor between retention and rapid renal excretion.

\section{Materials and methods}

\section{Sample collection}

Green and mature Moringa leaf samples were collected from several trees (about 3 trees in each area) in low-lying hot areas of Malawi where it grows naturally and the conditions are favorable for its growth. In these areas, average temperatures are $30^{\circ} \mathrm{C}$. The temperature can reach up to $40^{\circ} \mathrm{C}$ in the dry season. The sample collection areas, Lilongwe and Karonga, are along the lake shore of Lake Malawi and Shire River. These areas are generally hot and flat with sandy loam soils. Another Moringa oleifera sample was bought in USA from an Internet distributor (MoringaSource.com). This commercial product was originally imported from India and sold in the United States as powdered Moringa oleifera leaf packed in aluminum foil bags. Fresh sweet potato leaves (Covington variety) were harvested at the North Carolina State University Central Crops Research Station, Clayton, NC, washed and stored at $-20^{\circ} \mathrm{C}$ prior to use in this study. Fresh spinach leaves were bought from a local grocery store in Raleigh, NC, USA. All leaf samples were air dried, powdered in a mortar, and packaged in plastic bags. All samples were stored at room temperature and analyzed together at North Carolina State University.

\section{Evaluation of total calcium}

Total calcium in the samples was determined by atomic absorption spectrophotometry (AAS). Powdered dry leaf samples were subjected to dry-ashing before the determination of calcium. A $0.1 \mathrm{~g}$ sample of each material was weighed and ashed at $525^{\circ} \mathrm{C}$ for 8 hours. The ash was dissolved with $0.1 \% \mathrm{HCl}$ and $0.5 \%$ lanthanum oxide $\left(\mathrm{La}_{2} \mathrm{O}_{3}\right)$ followed by AAS analysis to determine calcium content.

\section{Evaluation of calcium digestibility}

In vitro digestion was used to determine calcium digestibility. The leaf powders were subjected to a simulated gastric phase followed by intestinal phase digestion, modified from the method of 
Fogleman et al. ${ }^{17}$. Pepsin enzyme from porcine gastric mucosa (Pcode 1000848645 Sigma-Aldrich, St. Louis, MO, USA) and hydrochloric acid were used in the gastric phase digestion. A $0.1 \mathrm{~g}$ sample of leaf powder was combined with $0.25 \mathrm{~mL}$ of pepsin solution (40 $\mathrm{mg}$ pepsin/mL of $0.1 \mathrm{M} \mathrm{HCl}$ ), and $\mathrm{pH}$ was then adjusted to 2.0 with additional $\mathrm{HCl}$. The mixture was incubated in a shaking water bath at $37^{\circ} \mathrm{C}$ for 120 strokes per minute for 2 hours, and then placed on ice for 10 minutes. $\mathrm{pH}$ was raised to 7 by adding $1 \mathrm{M}$ $\mathrm{NaHCO}_{3}$. This gastric digestion was followed by pancreatic enzymes (pancreatin from porcine pancreas, P1750, Sigma-Aldrich) and porcine bile extract (B8631, Sigma Aldrich) solution in the intestinal phase digestion. The enzyme stock contained $0.05 \mathrm{~g}$ pancreatin and $0.3 \mathrm{~g}$ bile extract in $25 \mathrm{~mL} 0.1 \mathrm{M} \mathrm{NaHCO}_{3}$. A $1.25 \mathrm{~mL}$ portion of the pancreatin-bile extract stock solution was added to each digested leaf sample, with additional incubation in a shaking water bath at $37^{\circ} \mathrm{C}$ for 120 strokes per minute for 2 hours. The mixtures were placed on ice for 10 minutes and adjusted to $\mathrm{pH} 7.2$ by addition of $0.5 \mathrm{M}$ $\mathrm{NaOH}$. All samples were brought to a common volume with distilled water and filtered through Whatman No.4 filter paper. The solution was diluted appropriately with $0.1 \mathrm{M} \mathrm{HCl}$ and $0.5 \%$ lanthanum oxide $\left(\mathrm{La}_{2} \mathrm{O}_{3}\right)$ followed by AAS analysis to determine calcium content.

\section{Evaluation of calcium bioaccessibility}

The bioaccessibility of calcium in the samples was determined by simulated in vitro absorption of calcium by using dialysis tubes. This involved the passive trans-membrane diffusion of calcium ions from one medium to another. A $10 \mathrm{~mL}$ portion of each sample (previously digested) was loaded inside of the dialysis tubing in a Floatalyzer ${ }^{\mathrm{TM}}$ G2 apparatus (Spectrum Laboratories, Inc., Rancho Dominquez, CA) by pipettes. The outside compartment of the dialysis tubing container for each sample was loaded with $25 \mathrm{~mL}$ of $0.9 \% \mathrm{NaCl}$ solution with $0.1 \%$ bovine serum albumin (fraction V, Sigma-Aldrich). The samples were then dialyzed at room temperature for 24 hours. The volumes of the solution outside and inside the dialysis tubing were measured and emptied in separate test tubes for calcium analysis. Calcium was analyzed by atomic absorption, and the calcium that was able to pass to the outside of the dialysis tubing corresponded to the bioaccessible calcium.

\section{Calculation of calcium bioaccessibility}

Bioaccessible calcium was calculated as the product of the calcium concentration in the external fluid and the combined fluid volume inside and outside the Floatalyzer ${ }^{\mathrm{TM}}$. The bioaccessibility of calcium was the amount of dialyzable calcium expressed as a percentage of total calcium in the sample. Calcium digestibility was calculated as the quantity of calcium in the filtrate divided by the calcium content in the original powdered leaf sample.

\section{Data analysis}

SAS and JMP software (SAS, Inc., Cary, NC) were used to statistically analyze the data. The Fit X by Y one-way analysis of variance subroutine was used to see the relationship among the two Moringa oleifera samples from Malawi, the Moringa oleifera sample from India, sweet potato leaves, and spinach in terms of calcium content, digestibility and bioaccessibility. The entire digestion procedure was replicated three times, using duplicate or triplicate samples in each replicate. Two samples of spinach, three samples of sweet potato leaves, and one sample from Moringa \#4 could not be included in the data analysis, because the atomic absorption spectrophotometer did not report a meaningful calcium concentration possibly due to consumption of the sample in the analyzer. Tukey's Studentized Range (TSR) test was used to determine whether or not significant differences existed in the mean values of the sample calcium content, digestibility and bioaccessibility at $\mathrm{P} \leq 0.05$.

\section{Results}

\section{Calcium content}

Calcium content and digestibility of Moringa oleifera, spinach and sweet potato leaves are provided in Table 1.

Calcium from the samples was expressed as percentage of the dry matter in the three Moringa oleifera and the spinach and sweet potato leaves. The results indicated that Moringa oleifera leaves had a higher percentage of calcium than spinach and sweet potato leaves. However, among the three Moringa oleifera samples, there was a significant difference in the percentage calcium content $(\mathrm{P}<0.05)$ using Tukey's Studentized Range Test at $\alpha=0.05$. The mean percentage calcium \pm SEM was $1.67 \pm 0.0011 .44 \pm 0.018$ and $1.55 \pm$ 0.00 for Moringa oleifera samples from India (M3), from Karonga, Malawi (M4) and another sample from Lilongwe, Malawi (M5), respectively. The mean percentage calcium in spinach and sweet potato leaves was $0.99 \pm 0.0003$ and $1.06 \pm 0.001$, respectively.

\section{Calcium digestibility}

The digestible calcium from Moringa oleifera samples and the control samples, spinach and sweet potato leaves are shown in Table 1.

Digestibility of calcium from the leaf powder was expressed as percentage of the calcium in dry matter that was solubilized by the digestion procedure. The digestibility results indicated that the three Moringa oleifera samples had higher digestible calcium than spinach and sweet potato leaves. Using Tukey's Studentized Range Test at $\alpha=0.05$, there was no significant difference in total digestible calcium between the two samples from Malawi, M4 and M5.

Table 1. Total calcium content as percent of dry matter, and digestible calcium as a percent of total $\mathrm{Ca}$ ( $\mathrm{g}$ solubilized $\mathrm{Ca} / 100 \mathrm{~g} \mathrm{Ca}$ in dried leaf $\times 100)$ from Moringa oleifera, spinach and sweet potato leaves (mean \pm standard error of the mean with $\mathrm{N}=2-4$ replicates per sample for total $\mathrm{Ca}, \mathrm{N}=3$ replicate experiments on duplicate or triplicate samples for digestible $\mathrm{Ca}$ ).

\begin{tabular}{|c|c|c|}
\hline Sample $^{1}$ & Total Ca (\%) (N) & Digestible $\mathrm{Ca}(\%)(\mathrm{N})$ \\
\hline s & $0.99 \pm 0.0003^{e}(2)$ & $1.35 \pm 0.21^{\circ}(5)$ \\
\hline SP & $1.06 \pm 0.001^{d}(2)$ & $3.79 \pm 0.23^{\circ}(4)$ \\
\hline M3 & $1.67 \pm 0.001^{a}(3)$ & $22.77 \pm 1.04^{b}(7)$ \\
\hline M4 & $1.44 \pm 0.018^{c}(4)$ & $46.57 \pm 8.34^{a}(6)$ \\
\hline M5 & $1.55 \pm 0.00^{b}(2)$ & $37.69 \pm 0.79^{a}(7)$ \\
\hline
\end{tabular}

'Samples: M3 = Moringa sample from India, M4 = first Moringa sample from Karonga, Malawi, M5 = second Moringa sample from Lilongwe, Malawi, $\mathrm{S}=$ spinach, $\mathrm{SP}=$ sweet potato leaves

${ }^{a b c}$ For the dependent variable within each column, the calcium sources (sample) in rows not connected by the same letter are significantly different from each other as determined by ANOVA and the Tukey-Kramer HSD test with $\alpha=0.05$. 
However, there was a significant difference in percentage of digestible calcium between Moringa oleifera samples from India and Malawi $(\mathrm{P}<0.05)$. The mean $( \pm \mathrm{SEM})$ percentage of digestible calcium was $22.77 \pm 1.04,46.57 \pm 8.34$ and $37.69 \pm 0.76 \%$ for Moringa oleifera samples from India (M3), from Malawi (M4) and the second sample from Malawi (M5), respectively. The mean percentage digestible calcium in spinach and sweet potato leaves were $1.35 \pm$ 0.21 , and $3.79 \pm 0.21 \%$, respectively.

\section{Bioaccessibility of calcium}

The bioaccessibility of calcium from Moringa oleifera samples and the control samples, spinach and sweet potato leaves, are provided in Table 2.

Bioaccessibility of calcium from the samples was expressed as percentage of the dry matter. Bioaccessible calcium was equivalent to dialyzable calcium. The bioaccessibility results from spinach and sweet potato leaves and the three Moringa oleifera samples indicated that Moringa oleifera had higher dialyzed calcium than spinach and sweet potato leaves. Using Tukey's Studentized Range Test at $\alpha=0.05$, there was no significant difference in total bioaccessible calcium between the two Moringa oleifera samples from Malawi, but these had more bioaccessible calcium than the Moringa oleifera sample from India. Also, the percentage bioaccessible calcium in all Moringa oleifera samples was greater than that in spinach and sweet potato $(\mathrm{P}<0.05)$.

Table 2 also shows the percentage of the digestible calcium that was dialyzable. Despite the substantial variation in the data, the table shows that a greater amount of the digestible calcium from spinach was dialyzable compared with the Moringa samples or sweet potato leaves, suggesting that the calcium oxalate in spinach is largely indigestible and remains in the initial filtrate, whereas the complexes that can be filtered can also pass through the dialysis membranes. The filtration step in the digestibility assay retained particles greater than 20-25 $\mu \mathrm{m}$ and allowed calcium in smaller particles to pass through the fluid that was used in the dialysis procedure. The

Table 2. Calcium bioaccessibility from Moringa oleifera,

spinach and sweet potato leaves. Values represent means \pm SEM of the number of replicates shown in parentheses.

\begin{tabular}{|lll|}
\hline Sample $^{1}$ & $\begin{array}{l}\text { Bioaccessible Ca } \\
\text { (\% of total Ca) (N) }\end{array}$ & $\begin{array}{l}\text { Dialyzable Ca as \% of } \\
\text { digestible Ca (N) }\end{array}$ \\
\hline S & $0.62 \pm 0.17^{\circ}(5)$ & $45.1 \pm 8.9^{\mathrm{a}}(5)$ \\
\hline SP & $0.85 \pm 0.08^{\mathrm{c}}(4)$ & $22.4 \pm 2.0^{\mathrm{b}}(4)$ \\
\hline M3 & $5.72 \pm 0.85^{\mathrm{b}}(7)$ & $24.8 \pm 3.3^{\mathrm{b}}(7)$ \\
\hline M4 & $10.03 \pm 1.36^{\mathrm{a}}(6)$ & $24.1 \pm 4.6^{\mathrm{b}}(6)$ \\
\hline M5 & $12.01 \pm 1.14^{\mathrm{a}}(7)$ & $31.8 \pm 2.7^{\mathrm{ab}}(7)$ \\
\hline
\end{tabular}

Samples: M3 = Moringa sample from India, M4 = first Moringa sample from Karonga, Malawi, M5 = second Moringa sample from Lilongwe, Malawi, S = spinach, SP = sweet potato leaves.

${ }^{a b c}$ For the dependent variable within each column, the calcium sources (sample) in rows not connected by the same letter are significantly different from each other as determined by ANOVA and the Tukey-Kramer HSD test with $\alpha=0.05$. dialysis membrane only allows molecular complexes from 500 to $1000 \mathrm{Da}$ to go through and be counted in the "bioaccessible" fraction. The bioaccessible fraction was $45 \%$ of the digestible calcium fraction for spinach, but only 22 to $32 \%$ for sweet potato and Moringa leaves (Table 2).

Data of calcium content, digestibility and bioaccessibility of

Moringa eoleifera, spinach and sweet potato leaves

1 Data File

http://dx.doi.org/10.6084/m9.figshare.943482

\section{Discussion}

In vitro methods for assessing the bioaccessibility of essential minerals are widely used because they are simple, fast, and inexpensive. Teixeira et al. ${ }^{18}$ recently measured in vitro digestibility of protein fractions in Moringa oleifera with different protein extraction pretreatments. The protein digestibility was relatively low, in contrast to the calcium bioaccessibility data we present here. Kamchan et al. ${ }^{19}$ used an in vitro method to study the bioavailability of calcium in vegetables, legumes and seeds; in their study, fresh vegetables were prepared by blanching in boiling deionized water for three minutes followed by homogenization in a food processor whereas seed and pod samples were cooked and homogenized in an electric blender and all the samples were stored in polyethylene bottles at $-20^{\circ} \mathrm{C}$ before analysis. In contrast, in our study Moringa oleifera leaf samples were air dried, pounded into powder and stored in polyethylene bags before being subjected to chemical analysis. We assessed calcium content, digestibility and bioaccessibility in Moringa oleifera leaf powder from Malawi and India, along with spinach and sweet potato leaf powder. There was a statistically significant difference in the percentage calcium content from the Moringa oleifera samples from India and the two samples from Malawi. This may be due to differences in the growing conditions because some soils have higher amounts of calcium. The amount of digestible calcium in the two Moringa oleifera samples from Malawi was statistically similar, and the samples from Malawi differed in this respect from the sample from India. This may be due to similar growing conditions for the samples from Malawi, which may differ from the growing conditions in India, or it may be due to genetic drift in the Moringa genome ${ }^{20}$. Dialyzed calcium was significantly different between the two samples from Malawi and one sample from India when a Tukey's Studentized Range Test with $\alpha=0.05$ was used. The dialyzed calcium from all the Moringa oleifera samples was significantly higher than spinach and sweet potato leaves. The bioaccessible calcium in spinach in this study was similar to the calcium bioavailability of spinach reported by Benway and Weaver ${ }^{2}$. In vitro methods used to study calcium dialyzability from different vegetables revealed percentage dialyzable calcium in kale, celery and Chinese cabbage to be $38.9 \pm 2.1,36.2 \pm 4.1$ and $32.2 \pm 4.6$, respectively ${ }^{19}$. This may be due to different chemical and biological compositions of these plants that inhibit absorption of calcium, such as phytate, oxalate, and dietary fiber, or due to different calculation methods. Ezeike et al. ${ }^{21}$ were able to extract $0.28 \mathrm{mg}$ of oxalate per 
gram of dry matter from Moringa oleifera leaves, and cited data to calculate that spinach contains $100 \mathrm{mg}$ oxalate per gram of dry matter. Oxalic acid in fresh sweet potato leaves was 3-5 mg per gram fresh weight, or about 16-27 mg per gram of dry matter ${ }^{22}$. The results from the study presented here are different from those found by Kamchan et al. ${ }^{19}$ probably because different species of plants and different sample preparatory methods were used. An in vitro iron bioavailability study ${ }^{16}$ found that boiling the fresh leaves and dried powder of Moringa oleifera enhanced the in vitro iron bioavailability by 3.5 and 3 times, respectively. Whether a similar preparatory method would enhance the calcium bioaccessibility requires further study.

Price $^{12}$ found calcium content in Moringa oleifera pods, leaves and leaf powder to be $30 \mathrm{mg}, 440 \mathrm{mg}$ and $2003 \mathrm{mg}$ per $100 \mathrm{~g}$ of edible portion, respectively. We found in our study that the percentage calcium content in powdered Moringa oleifera leaves is $1.67 \pm 0.001$ for samples from India (M3), $1.44 \pm 0.018$ for samples from Karonga, Malawi (M4), and $1.55 \pm 0.00$, for samples from Lilongwe, Malawi (M5). If we translate these results per $100 \mathrm{~g}$ edible sample, it yields $1.67 \mathrm{~g}(1670 \mathrm{mg}), 1.44 \mathrm{~g}(1440 \mathrm{mg})$ and $1.55 \mathrm{~g}(1550 \mathrm{mg})$ for M3, M4, and M5, respectively, averaging $1553 \mathrm{mg} / 100 \mathrm{~g}$. These results are not very different from that of Price ${ }^{12}$ for the leaf powder, which was $2003 \mathrm{mg}$ per $100 \mathrm{~g}$ sample. The current calcium RDA for pregnant and lactating women is $1300 \mathrm{mg} /$ day for women aged $14-18$ years and $1000 \mathrm{mg} /$ day for women aged $19-50$ years $^{23}$. A dietary intake study undertaken in Malawi, Africa, showed that calcium intake from women was lower than the recommended intake with average intake of $620 \mathrm{mg} / \mathrm{day}$ for non-lactating women and $622 \mathrm{mg} / \mathrm{day}$ for lactating women ${ }^{24}$. Another nutrient intake study conducted in South Africa in three ethnic groups (black, white and mixed ancestry subjects) found that mean dietary calcium intake was higher in white subjects than in black and mixed ancestry subjects; however, calcium intake was low in all the groups with about half of the RDA of $1000 \mathrm{mg} / \mathrm{day}^{25}$. If the dietary intake of Moringa oleifera is increased, calcium intake could also be tremendously increased, especially in developing countries such as Malawi, where growing these trees requires little care. This can be achieved by promoting plantation of these trees in areas where they grow easily.

According to our study, only $64 \mathrm{~g}$ of dried Moringa leaf powder would supply the $1000 \mathrm{mg}$ /day RDA. From this intake, $357 \mathrm{mg}$ of calcium are estimated to be digestible, and $93 \mathrm{mg}$ of calcium are estimated to be bioaccessible, or available for absorption, based on the average of the Moringa oleifera plant samples tested in our study. This study also shows sweet potato leaves to be a good source of calcium but more similar to spinach than to Moringa oleifera leaves.

\section{Conclusion}

The percentage dialyzed or bioaccessible calcium is higher in Moringa oleifera leaves than other vegetable sources such as spinach and sweet potato leaves. Percentage dialyzed calcium of Moringa oleifera grown in Malawi was slightly higher than the sample grown in India. Because there is evidence from related research that percentage calcium dialyzability differs in different foods, especially vegetable foods because different inhibitory components may be present, additional research can be conducted to find out the inhibitory components in Moringa oleifera leaves. Such inhibitory components may be the contributing factors for the differences in percentage bioaccessible calcium in different plant leaf samples.

\section{Data availability}

figshare: Data of calcium content, digestibility and bioaccessibility of Moringa oleifera, spinach and sweet potato leaves http://dx.doi. org/10.6084/m9.figshare. $943482^{26}$

\section{Author contributions}

JCA was responsible for editing the manuscript, experimental design and final data analysis. JYI proposed the research area, developed methods and wrote the first draft of the manuscript. YC conducted the laboratory analyses and prepared the data for analysis.

\section{Competing interests}

The authors have no competing interests in the publication of this paper.

\section{Grant information}

This research was supported by grants from USAID - UILTCBMalawi in a subcontract from Michigan State University, and by the North Carolina Sweet Potato Commission to author JCA.

The funders had no role in study design, data collection and analysis, decision to publish, or preparation of the manuscript.

\section{Acknowledgements}

Thanks to Ruth Watkins, the laboratory manager of the Nutrition Technical Services Lab, Food, Bioprocessing and Nutrition Sciences Department at NC State University and Dr April D. Fogleman for their assistance and guidance in conducting the laboratory analysis, and to Lusungu G. Mwaungulu for collection of Moringa leaf. Thanks to Dr Van-Den Truong and Katie Maloney for collection and preparation of sweet potato leaves. This research was conducted and submitted in a thesis for partial fulfillment of the Master of Science degree for author JYI at North Carolina State University.
1. Bronner F, Pansu D: Nutritional aspects of calcium absorption. J Nutr. 1999; 129(1): 9-12. PubMed Abstract

2. Benway DA, Weaver CM: Assessing chemical form of calcium in wheat, spinach, and kale. J Food Sci. 1993; 58(3): 605-608. Publisher Full Tex
3. Zhang Y, LiY, Wei J, et al.: Effects of nitrogen and calcium nutrition on oxalate contents, forms, and distribution in spinach. J Plant Nutr. 2009; 32(12): 2123-2139.

Publisher Full Text

4. Mbaeyi-Nwaoha IE, Emejulu VN: Evaluation of phytochemical composition and antimicrobial activity of sweet potato (Ipomoea batatas) leaf. Pakistan J Nutr. 
2013; 12(6): 575-586

Reference Source

5. Franceschi VR, Nakata PA: Calcium oxalate in plants: formation and function. Ann Rev Plant Biol. 2005; 56: 41-71.

PubMed Abstract | Publisher Full Text

6. Ghaly AE, Alkoaik FN: Extraction of protein from common plant leaves for use as human food. Amer J Applied Sci. 2010; 7(3): 331-342.

Reference Source

7. Mwanri AW, Kogi-Makau W, Laswai HS: Nutrients and antinutrients composition of raw cooked and sun-dried sweet potato leaves. African J Food Agric Nutr Dev. 2011; 11(5).

Publisher Full Text

8. Chen CM, Li SC, Chen CY, et al:: Constituents in purple sweet potato leaves inhibit in vitro angiogenesis with opposite effects ex vivo. Nutrition. 2011; 27(11-12): 1177-1182. PubMed Abstract | Publisher Full Text

9. Siddhuraju P, Becker K: Antioxidant properties of various solvent extracts of total phenolic constituents from three different agroclimatic origins of drumstick tree (Moringa oleifera Lam.) leaves. J Agric Food Chem. 2003; 51(8): 2144-2155.

PubMed Abstract | Publisher Full Text

10. Ferreira PMP, Farias DF, Oliveira JTA, et al:: Moringa oleifera: bioactive compounds and nutritional potential. Revista de Nutricao Campinas. 2008; 21(4): 431-437.

Publisher Full Text

11. Popoola JO, Obembe OO: Local knowledge, use pattern and geographical distribution of Moringa oleifera Lam. (Moringaceae) in Nigeria.

J Ethnopharmacol. 2013; 150(2): 682-69. PubMed Abstract | Publisher Full Text

12. Price ML: The Moringa Tree. ECHO Technical Note. Educational Concerns for Hunger Organization, N. Ft. Meyers, FL. 1985. Reference Source

13. Dahot MU, Memon AR: Nutritive significance of oil extracted from Moringa oleifera seeds. J Pharm Univer Karachi. 1985; 3(2): 75-80.

14. Oduro I, Ellis WO, Owusu D: Nutritional potential of two leafy vegetables: Moringa oleifera and Ipomea batatas leaves. Scientific Research Essay. 2008 3(2): $57-60$.

Reference Source

15. Yang RY, Chang LC, Hsu JC: Nutritional and Functional Properties of Moringa Leaves-From Germplasm, to Plant, to Food, to Health. Accra, Ghana, November $16-18,2006$

Reference Source
16. Yang RY, Tsou STS, Lee TC: Effect of cooking on in vitro iron bioavailability of various vegetables. In TC Lee and CT Ho (eds.), Bioactive compoundsin foods: effect of processing and storage. American Chemical Society, Washington, D.C. 2002; p130-142. Publisher Full Text

17. Fogleman AD, Cohen RS, Sakamoto P, et al.: Effect of added calcium, phosphorus, and infant formula on calcium and phosphorus dialyzability in preterm donor human milk. J Ped Gastroenterol Nutr. 2012; 55(4): 390-397. PubMed Abstract | Publisher Full Text

18. Teixeira EM, Barbieri Carvalho MR, Neves VA, et al:: Chemical characteristics and fractionation of proteins from Moringa oleifera Lam. leaves. Food Chem. 2014 147: $51-54$.

Publisher Full Text

19. Kamchan A, Puwastien P, Sirichakwal PP, et al:: In vitro calcium bioavailability of vegetables legumes and seeds. J Food Comp Anal. 2004; 17(3-4): 311-320. Publisher Full Text

20. Muluvi GM, Sprent Jl, Soranzo N, et al:: Amplified fragment length polymorphism (AFLP) analysis of genetic variation in Moringa oleifera Lam. Mol Ecol. 1999; 8(3): 463-470.

PubMed Abstract | Publisher Full Text

21. Ezeike CO, Aguzue OC, Thomas SA: Effect of brewing time and temperature on the release of manganese and oxalate from Lipton tea and Azadirachta indica (Neem), Phyllanthus amarus and Moringa oleifera blended leaves. J Appl Sci Environ Management. 2011; 15(1): 175-177. Publisher Full Text

22. Almazan AM: Antinutritional factors in sweet potato greens. J Food Comp Analysis 1995; 8(4): 363-368. Publisher Full Text

23. IOM (Institute of Medicine). Dietary Reference Intakes for Calcium and Vitamin D. Washington DC: National Academy Press. 2011. PubMed Abstract

24. Hullund J, Hatloy A, Benesi I, et al:: Snacks are important for fat and vitamin intakes among rural African women: a cross-sectional study from Malawi. Eur J Clin Nutr. 2008; 62(7): 866-871. PubMed Abstract | Publisher Full Text

25. Charlton KE, Steyn K, Levitt NS, et al.: Diet and blood pressure in South Africa: intake of foods containing sodium, potassium, and magnesium in three ethnic groups. Nutrition. 2005; 21(1): 39-50. PubMed Abstract | Publisher Full Text

26. Allen JC, Issa JY, Cai W: Data of calcium content, digestibility and bioaccessibility of Moringa oleifera spinach and sweet potato leaves. Figshare. 2014.

Data Source 


\section{Open Peer Review}

\section{Current Peer Review Status: ? ? ?}

\section{Version 1}

Reviewer Report 07 July 2014

https://doi.org/10.5256/f1000research.3527.r4972

(C) 2014 Mårtensson L. This is an open access peer review report distributed under the terms of the Creative Commons Attribution License, which permits unrestricted use, distribution, and reproduction in any medium, provided the original work is properly cited.

\section{Linda Mårtensson}

Department of Food Science, Swedish University of Agricultural Science, Uppsala, Sweden

The article "Calcium content, in vitro digestibility, and bioaccessibility in leaves of spinach (Spinacia oleracea), sweet potato (Ipomea batatas), and drumstick tree (Moringa oleifera)" by Allen et al. concerns important issues of Calcium intake when dairy products are replaced, irrespective of the cause behind the need or desire to the substitution. The findings are valuable for global nutritional security as well as for further research. However, I find numerous ways to improve the publication in its current format.

\section{Overall suggestions for improvement:}

1. The use of Latin name and common name should be done in a more consistent style throughout the entire article. Latin should preferably be used as the standard throughout the article and for all species/crops in the study.

2. The number of significant digits should also be consistent throughout the article: e.g. 0.99 has two but 1.54 has three.

3. Use of abbreviations: the first time a term is used is should be spelled out and then can be written as an abbreviation in brackets after. In the continued text use the abbreviation only, e.g. $\mathrm{HCl}$ is used before the spelled out hydrochloric acid.

\section{Specific suggestions for improvement:}

\section{Abstract}

1. The sentence "... revealing that bioaccessible calcium in sweet potato leaves was a nonsignificant 1.4 times higher and in Moringa was 9.2 to 19.4 times higher than in spinach." must be clarified. The results provide more information than this and can be summarized in the abstract. 
2. Add \% after results in second paragraph.

3. Second paragraph: "...1.4 times higher than..." - what are you comparing to?

Introduction - no comments

\section{Materials and methods}

1. Page 4, line 18: "common volume" - The authors are advised to give the actual volume here.

2. Title "Calculation of calcium bioaccessibility" should include digestibility.

3. Keep the order in presentation - e.g. digestibility should be presented first in "Calculation of calcium bioaccessibility" to follow earlier flow.

4. Page 4, second column: "because the atomic absorption spectrophotometer..." - Clarify this.

5. $P$ value and alfa are mixed throughout the results section, which needs to be either clarified or changed.

\section{Results}

1. Both starting sentences in the "Results" section are misplaced. They would perhaps be better off in the materials and methods section?

2. Table 1: hyperlinks (and explanations?) are missing for indications $d$ and e.

3. Results need not be repeated in result text if already presented in tables.

4. Results need not to be repeated in the discussion.

\section{Discussion}

1. Soil chemistry is reflected upon but information/data is lacking - Is it possible to supplement?

2. Results should not be repeated here.

Competing Interests: No competing interests were disclosed.

I confirm that I have read this submission and believe that I have an appropriate level of expertise to confirm that it is of an acceptable scientific standard, however I have significant reservations, as outlined above.

Reviewer Report 06 June 2014

https://doi.org/10.5256/f1000research.3527.r4973

(C) 2014 Cilla A. This is an open access peer review report distributed under the terms of the Creative Commons Attribution License, which permits unrestricted use, distribution, and reproduction in any medium, provided the original work is properly cited.

\section{Antonio Cilla}

Nutrition and Food Chemistry, Faculty of Pharmacy, University of Valencia, Burjassot, Valencia, 
Spain

The manuscript of Prof. Allen and colleagues highlights the potential use of leaves of spinach, sweet potato and drumstick tree as an alternative to other calcium dietary sources such as milk and dairy products. In addition they measure the bioaccessibility, as a prior step of bioavailability, to check if these leaves can be a potential source of available calcium in the geographic areas in which they are grown or cultivated easily and are a cost-effective approach for people in these zones. Research in this field is very important in food science and nutrition since results of this kind provide a scientific rationale, as mentioned by the authors, to improve nutrition, boost food security, foster rural development and support sustainable land care. However, I suggest some modifications to improve the study.

1. Bioaccessibility (defined as a fraction of a compound that is released from its food matrix within the gastrointestinal tract and that becomes available for absorption) is a term which comprises both solubility and dialyzability (Fernández-García et al. Nutr. Res. 2009, 29, 751-760). The results, as demonstrated in many other publications, should be expressed as \% bioaccessibility (understood as \% dialysis or \% solubility). See examples (Perales et al. J. Agric. Food Chem. 2005, 53, 3721-3726 or Galán et al. J. Agric. Food Sci. 2014, 94, 515-521). This should be applied to the entire text.

\section{Abstract:}

2. Second Paragraph - "revealing that bioaccessible calcium in sweet potato leaves was a nonsignificant 1.4 times higher ..." - what is this in comparison to?

\section{Introduction:}

3. Polyphenols can also bind calcium and other divalent minerals and thus reduce their bioavailability. - This should be included in the introduction.

4. You need to specify that there is fewer data on calcium bioavailability and bioaccessibility.

\section{Materials and methods:}

5. Evaluation of calcium bioaccessibility: the authors should indicate in the last sentence that this "...corresponded to the bioaccessible (dialyzable) calcium."

\section{Results:}

6. As reported by the previous reviewer (Dr. Failla) please do not duplicate table results in the text. 7. In table 2 the nomenclature in the 2 nd column needs to be changed to Ca bioaccessibility (\% of total Ca).

8. How are the authors sure that the complexes formed are with oxalate and not with phytate and/or polyphenols?

\section{Discussion:}

9. I do not understand why authors compare bioaccessibility of calcium with that of proteins from the study of Teixeira et al.

10. The authors introduce the study of Kamchan et al. but do not include anything about this study's findings or compare them with their own results.

11. Sometimes the terms bioavailability and bioaccessibility are used indistinctly, but they are not the same. The authors are comparing bioaccessibility with bioaccessibility (solubility) and not bioavailability in the work of Benway and Weaver. This must be modified. 
Competing Interests: No competing interests were disclosed.

I confirm that I have read this submission and believe that I have an appropriate level of expertise to confirm that it is of an acceptable scientific standard, however I have significant reservations, as outlined above.

Reviewer Report 14 March 2014

https://doi.org/10.5256/f1000research.3527.r4129

(c) 2014 Failla M. This is an open access peer review report distributed under the terms of the Creative Commons Attribution License, which permits unrestricted use, distribution, and reproduction in any medium, provided the original work is properly cited.

\section{Mark L Failla}

Department of Human Nutrition, Ohio State University, Columbus, $\mathrm{OH}$, USA

This article by Prof. Allen and associates addresses the important issue of inadequate intake of calcium by those who do not have access to, or the ability/willingness to consume milk and dairy products. The possibility that leaves from three common plant foods in rural areas or developing countries can serve as an alternative source of calcium merits investigation. The results provide novel information regarding calcium content and dialyzability in dried powders of leaves from spinach, sweet potato and drumstick. These results will be of interest to nutrition and food scientists, horticulturists and food processors.

I have several specific suggestions for enhancing the presentation:

1. Abstract: Use of the term "mock serum solution" is a stretch for the presence of BSA outside the dialysis bag. Plasma contains numerous proteins and low molecular weight compounds that can bind a portion of plasma calcium. The rationale for use of BSA should be added to the manuscript e.g., serves as a "sink" for calcium diffusing into the outer solution, some calcium in plasma and some of the divalent metal in plasma complexes with albumin. I suggest that albumin be substituted for mock serum solution.

2. Abstract: middle of paragraph 2. "Moringa oleifera had higher calcium content.....". Add \% after 0.99 and 1.06 .

3. Abstract: paragraph 2. "A dialysis system was designed..." "1.4 times higher" - than what?

4. The term bioaccessibility generally refers to availability for uptake by, or paracellular transfer across the epithelial cell barrier. Passive diffusion across the barrier represents a portion of calcium absorption; particularly when the lumen concentration of soluble calcium is relatively high. As the investigators determined the amount of dialyzable calcium I suggest that it is not appropriate to use the term bioaccessibility in the title and throughout the manuscript. The great majority of papers reporting results for electrolytes and low molecular weight organic compounds obtained using in vitro digestion coupled with dialysis 
refer to dialyzability; not bioaccessibility.

5. Results: The text and tabular data are quite redundant with means and SD from the table stated in text. The text can be less specific, i.e., delete the numerical details.

6. Discussion: The translation of the in vitro results to the amount of calcium provided by powdered leaves is excellent. However, individuals in poor rural areas of developing countries generally consume boiled leaves from the three plants. How much calcium would 1 serving of leaves from each plant provide? Might a distinction of use of these leaves in a dried form as a supplement vs as an actual food, provide a more balanced viewpoint?

Competing Interests: No competing interests were disclosed.

I confirm that I have read this submission and believe that I have an appropriate level of expertise to confirm that it is of an acceptable scientific standard, however I have significant reservations, as outlined above.

The benefits of publishing with F1000Research:

- Your article is published within days, with no editorial bias

- You can publish traditional articles, null/negative results, case reports, data notes and more

- The peer review process is transparent and collaborative

- Your article is indexed in PubMed after passing peer review

- Dedicated customer support at every stage

For pre-submission enquiries, contact research@f1000.com 